Rok XV (2020) | 2 (30) | S. 135-148

https://doi.org/10.12797/LV.15.2020.30.11

\author{
Andrzej Kominek ๑ \\ Uniwersytet Jana Kochanowskiego, Kielce \\ jedruskom@poczta.onet.pl
}

\title{
„MÓWIENIE ZA KIMŚ" JAKO JĘZYK BEZ KOMUNIKACJI
}

Słowa klucze: funkcje języka, autyzm, echolalia, funkcja autostymulacyjna

Keywords: functions of the language, autism, echolalia, self-stimulation function

\section{Wprowadzenie}

Poszukiwanie istoty języka ${ }^{1}$ jest bodaj najważniejszym przedmiotem zainteresowania językoznawców, semiologów, filozofów i innego rodzaju badaczy języka i kultury $^{2}$. Wydana po polsku w 2018 r. książka Siódma funkcja języka Laurenta Bineta, francuskiego pisarza i wykładowcy akademickiego, pokazuje, w formie powieści

1 Wyrażenie to nawiązuje do zbioru artykułów Romana Jakobsona (1989a), w którym znajduje się jeden z najbardziej znanych tekstów tego uczonego, poświęcony sześciu funkcjom językowym: poznawczej, emotywnej, konatywnej, poetyckiej, fatycznej i metajęzykowej (Jakobson 1989b: 77124). Słowo wyjaśnienia na wstępie tych rozważań należy się również kwestii używanego w artykule wieloznacznego terminu język. Przyjmuję za Renatą Grzegorczykową, że mówiąc o funkcjach języka czy tekstu, zawsze mamy na myśli język jako parole (tak samo należy rozumieć funkcje językowe Jakobsona). „Mówienie o funkcjach języka jest pewnym skrótem: »funkcja języka polegająca na zdolności tworzenia tekstów o określonej funkcji«" (Grzegorczykowa 1991: 17). W takim więc znaczeniu używam w tekście (zaczynając od tytułu) terminu język. Warto natomiast nadmienić, że we własnej klasyfikacji prof. Grzegorczykowa dokonuje wyraźnego oddzielenia funkcji tekstu od funkcji języka.

2 Sam R. Jakobson zajmował się m.in. semiotyką, ogólną teorią języka, typologią systemów fonologicznych, prozodią, wersyfikacją, morfologią, teorią języka poetyckiego, a także patolingwistyką i neurolingwistyką. 
spiskowej z wielkimi filozofami i semiologami w rolach głównych, że istoty języka poszukują różni „władcy słów”, upatrując jej w rzekomo magicznej mocy, pozwalającej przejmować kontrolę nad myślami i działaniami ludzi³

Samo pojęcie „siódmej funkcji” języka łączy się przede wszystkim z Romanem Jakobsonem, którego wykład o sześciu funkcjach językowych jest kilkakrotnie przytoczony w powieści L. Bineta. Jeden z głównych bohaterów książki, doktorant Simon, próbuje wiązać „siódmą funkcję” $\mathrm{z}$ opisywaną również przez R. Jakobsona funkcją magiczną (zaklinającą), którą rosyjski badacz definiuje jako „przemianę nieobecnej albo nieistniejącej trzeciej osoby w odbiorcę konatywnego komunikatu: [np. - A.K.] Niech mu ręka uschnie!" (Jakobson 1989b: 84)4.

$\mathrm{O}$ wiele więcej oczekuje się $\mathrm{w}$ całym tym poszukiwaniu od funkcji wiązanej z parą nazwisk Austin-Searle, którą ci brytyjscy filozofowie języka nazwali performatywną (sprawczą) $)^{5}$ W rozmowie, którą prowadzi Simon z policjantem Bayardem, pojawia się w sposób przejaskrawiony oczekiwanie, że owa funkcja będzie działała bez ograniczeń:

Teoria Austina to performatyw, pamiętasz? Akty illokucyjne i perlokucyjne. Kiedy powiedzieć znaczy zrobić. Kiedy się robi coś, mówiąc. Kiedy się zmusza ludzi do zrobienia czegoś, po prostu mówiąc do nich. Na przykład gdybym miał bardziej konsekwentną siłę perlokucyjną, niż mam, albo gdybyś ty nie był takim dupkiem, wystarczyłoby mi powiedzieć „referat Derridy”, żebyś wskoczył w buty i już byśmy szli rezerwować miejsca [wyróżnienie A.K.] (Binet 2018: 317).

W poszukiwaniach superfunkcji języka trop prowadzi do tajnych praktyk ludzi obdarzonych talentem oratorskim, którzy mają na celu popisywanie się szczególnymi umiejętnościami językowymi. Jest tu przywołanie osoby intelektualnego guru, którego miejsce zajmuje słynny włoski semiolog Umberto Eco, poprzez nawiązanie do jego z kolei spiskowej powieści Imię Róży. Eco został wykreowany przez L. Bineta na mistrza tajnej organizacji Logos Klub ${ }^{6}$. Organizacja ma strukturę piramidalną:

3 Autor wykorzystuje tu znane koncepcje interdyscyplinarne, będące rodzajem interpretacji odwiecznych marzeń i poszukiwań naukowych. Przedstawienie ich przez pryzmat intrygującej fabuły, konstruującej trzymający w napięciu thriller naukowo-intelektualny, jest o wiele ciekawsze niż suchy wykład akademicki, do którego jest przyzwyczajony.

4 Ograniczam się tu z konieczności do, mocno już dziś zdezaktualizowanej, teorii R. Jakobsona, wybierając ją z dwóch powodów: jako teorię najbardziej znaną i pełniącą kluczową funkcję w tekście powieści Laurenta Bineta. Czytelnik znajdzie bardzo dobry przegląd prac na temat funkcji języka i tekstu w artykule R. Grzegorczykowej Problem funkcji języka i tekstu w świetle torii aktów mowy (1991).

5 Zob. Austin 1974, 1993; Searle 1980, 1987.

6 Z opowieści Eco wynika, że pewna heretycka sekta założyła w III w. po Chrystusie organizację Logi Consilium, która rozprzestrzeniła się w Italii, następnie we Francji, gdzie w XVIII w., podczas rewolucji, przybrała nazwę Logos Klub. 
na czele stoją sofiści, którym przewodniczy Protagoras Magnus, a niższe szczeble zajmują trybuni, perypatetycy, dialektycy, oratorzy i retorzy oraz najniżej stojący, czyli tzw. mówiący. Tajność stowarzyszenia bierze się stąd, że za przegrany pojedynek słowny w walkach oficjalnych płaci się wysoką cenę - utratę palca. W skrajnych przypadkach, gdy tzw. mówiący wyzwie na pojedynek mistrza i przegra, może zostać potwornie okaleczony przez obcięcie przyrodzenia. Eco w rozmowie z Simonem tłumaczy, że w obrębie Logos Klubu istnieją dwa wielkie nurty: immanentyści, którzy w takich potyczkach oratorskich widzą cel sam w sobie, oraz funkcjonaliści, którzy traktują je jako środek do osiągnięcia różnych celów. W usta Eco wkłada autor słowa, które odnoszą się poniekąd do nieosiągalnego efektu działania „siódmej funkcji” języka. Upatruje on go w funkcji performatywnej, perlokucyjnej bądź manipulacyjnej, podnosząc jej działanie aż do granic absurdu:

Ten, kto by znał tę funkcję i opanował ją, byłby wirtualnie panem świata. Jego potęga byłaby nieograniczona. Mógłby wygrywać wszystkie wybory, porywać tłumy, wywoływać rewolucje, uwodzić wszystkie kobiety, sprzedawać wszystkie produkty, jakie tylko można sobie wyobrazić, budować imperia, oszukiwać cały świat, uzyskiwać wszystko, czego by chciał, w każdych okolicznościach (ibid.: 242).

W powieści L. Bineta pojawia się też spostrzeżenie na temat charakteru sprawczego formuł biblijnych i religijnych. Słowa z Księgi Rodzaju: „Niech się stanie światłość. I stała się światłość" są najstarszym przykładem performatywu odnalezionego dotąd w świecie judeochrześcijańskim w rękopisie z Morza Martwego z drugiego wieku przed Chrystusem (ibid.: 311$)^{7}$.

Zagadnienie tego, czy tzw. „siódma funkcja” języka powinna znaleźć się w schemacie R. Jakobsona (a zdaniem prezentowanych tu językoznawców i uczonych tak), jest niejako brakującym, ale dobrze rozpoznanym ogniwem w poszukiwaniu istoty języka, tak że umyka tu uwadze banalny, ale najbardziej podstawowy cel jego istnienia, ku któremu kierują się wszystkie pozostałe funkcje językowe. Mowa oczywiście o funkcji komunikacyjnej. Sam R. Jakobson mówi o wyróżnionych przez siebie sześciu funkcjach jako elementach aktu komunikacji (1989b), ponieważ w każdej $\mathrm{z}$ nich jest realizowana w określony sposób nadrzędna funkcja, którą możemy nazwać komunikacyjną ${ }^{8}$.

W dalszym ciągu tego artykułu interesować mnie będą funkcje języka osób $\mathrm{z}$ autyzmem porównane z ujęciem R. Jakobsona. Czy ich język jest inny, bo inne są jego funkcje? Czy można tu mówić o jakimś odpowiedniku superfunkcji językowej,

7 Zob. też na temat innych funkcji formuł sprawczych obecnych w religii w: Grün 2016: 199-209.

8 Przyjmuję tu z konieczności uproszczony model, odnosząc funkcje językowe do pojęcia języka (langue). Całość zagadnienia doczekała się wielu opracowań i towarzyszącej im dyskusji (zob. Bartmiński, Grzegorczykowa 1991), w tym również na temat innych funkcji, nieujętych w schemacie Jakobsona, np. funkcji sprawczej (magicznej). Zob. na ten temat np.: Budziszewska 1991; Burszta 1991; Engelking 1991. 
która jest charakterystyczna dla osób tzw. neurotypowych? Jaka funkcja najpełniej określa język autyków?

\section{Istota języka osób z autyzmem}

W przeszłości sporadycznie pojawiały się próby klasyfikacji stopnia zdolności posługiwania się mową przez osoby z autyzmem (zob. m.in.: Konstantareas 1992; Minczakiewicz 1994; Markiewicz 2004). Nie były one w pełni efektywne, chociaż zastosowane w nich kryteria podziału są logiczne (Mary Konstantareas - dokładna matryca różnych deficytów; Elżbieta Minczakiewicz - stopniowanie umiejętności komunikacyjnych; Katarzyna Markiewicz - różne poziomy jakościowe komunikacji językowej ${ }^{9}$ ). W związku z tym zaproponowałem całkiem inny, moim zdaniem prostszy, podział funkcjonalny (Kominek 2014a). Opierając się na podziale zwanym kontinuum zaburzeń autystycznych, podzieliłem wszystkie dzieci (osoby z autyzmem) na mówiące i niemówiące. Osoby $\mathrm{z}$ autystycznego spektrum posługujące się mową dzielą się z kolei na mówiące swoimi słowami, których wypowiedzi są spontaniczne i sensowne, oraz posługujące się cudzymi słowami, czyli tzw. echolalią. Pierwszy typ stanowią osoby lepiej funkcjonujące (z zespołem Aspergera), drugi - osoby z autyzmem, z tym jednak uzupełnieniem, że u tych z autyzmem występuje echolalia czysta albo z domieszką spontanicznych zachowań językowych.

Pełna lub częściowa intencjonalność nie stanowi istoty języka autyków. Ich mowa jest nieautonomiczna, kopiowana, nieintencjonalna. Wyróżnia ona głównie autyków niskofunkcjonujących. Około trzech czwartych populacji dzieci z autyzmem posługuje się mową w różnym stopniu echolaliczną (Frith 2008: 154) ${ }^{10}$. Nawet jeśli weźmiemy pod uwagę fakt, że zarówno w normalnym rozwoju, jak i w patologii rozwojowej echolalia zanika w miarę postępów językowych dziecka, to i tak zjawisko to dotyczy dużej liczby osób.

Echolalia, zwana też potocznie papugowaniem ze względu na bezrefleksyjne naśladownictwo mowy, polega na bezpośrednim lub odroczonym powtarzaniu z podobną intonacją, w sposób mimowolny i automatyczny dźwięków, wyrazów, całych zdań, a nawet dłuższych i bardzo długich tekstów ${ }^{11}$. Autycy powtarzają nie tylko słowa usłyszane $\mathrm{w}$ danej chwili, ale też przypominają je sobie, gdy stykają się z ja-

9 Katarzyna Markiewicz wyróżnia trzy grupy dzieci autystycznych: te, które w ogóle nie przyswoiły sobie zasad komunikacji językowej, te, u których pojawia się echolalia, i dzieci, które posługują się językiem metaforycznym i neologizmami, ale w stopniu ograniczonym.

10 Objawy te można odnieść do zaburzeń tworzenia reprezentacji umysłowych, charakterystycznych również dla osób z afazją, znajdujących się w demencji, schizofrenii dziecięcej, stanach kataleptycznych czy histerii.

11 W niektórych chorobach echolalia poza powtarzaniem werbalnym obejmuje także naśladowanie ruchów (echopraksja) lub mimiki (echomimia). 
kimś sygnałem nawiązującym w sposób werbalny lub zdarzeniowy do wcześniejszej sytuacji (por. m.in. ibid.: 154-157; Winczura 2008: 34-35; Sadowska 2011: 42; Pisula 2012: 41; Korendo 2013: 88-92; Bobkowicz-Lewartowska 2014: 60-62).

Według Uty Frith echolalia jest „wyraźnym przejawem oderwania peryferyjnych systemów przetwarzania od systemu centralnego, który zajmuje się znaczeniami" (Frith 2008: 155). Elementy języka przyswojone na poziomie opanowania struktury gramatycznej mowy nie mogą być zinterpretowane znaczeniowo na wyższym poziomie. Wygląda to tak - pisze U. Frith, używając efektownej metafory - „jakby wody dopływów wielkiej rzeki nie docierały do niej, lecz wsiąkały wcześniej w piach" (Frith 2008: 155).

Marta Korendo dostrzega echolalię u dzieci na wszystkich poziomach języka, począwszy od zachowań niewerbalnych typu dźwięki gardłowe, ustne i nosowe wydobywane przez różne osoby w sposób oryginalny i niepowtarzalny. Dalej dzieci mogą powtarzać ciągi sylab lub zbitek sylabowych samodzielnie wymyślonych. Najczęściej występujący rodzaj echolalii dotyczy powtarzania słów i fraz (Korendo 2013: 88-89). Należałoby tu jeszcze wymienić zmianę kategorii osoby, tzn. zastępowanie najczęściej 1. os. lp. przez 2. lub 3. lp. (np. zamiast powiedzieć Chcę zabawkę. dziecko użyje zwrotu zawierającego własne imię, czyli Ania chce zabawkę.). Ponadto echolalia może dotyczyć płaszczyzny większych jednostek, typu monolog wielozdaniowy, dialog, a także dłuższych tekstów zasłyszanych najczęściej w telewizji lub podczas oglądania filmu.

Niektórzy badacze wymieniają również tzw. stereotypie, które są manifestacją powtarzanych elementów na płaszczyźnie pozajęzykowej i językowej. Dzieci autystyczne są przywiązane do tych samych zabawek, przedmiotów albo rutynowych działań, np. przestrzegania pedantycznego porządku. W sferze działań językowych powtarzają te same słowa lub wypowiedzi, np. treści reklam czy fragmenty tekstów filmowych. Echolalie są więc częścią i podstawą zachowań stereotypowych, czego badacze najczęściej nie zauważają. Stereotypię, obejmującą teksty krótkie i długie, i echolalię, zarówno bezpośrednią, jak i odroczoną, łączy mechanizm, który nazywam w tym artykule „mówieniem za kimś”. Uciekanie się do stereotypii wszelkiego rodzaju pojawia się najczęściej w warunkach podwyższonego napięcia emocjonalnego. Osoby z autyzmem „zacinają się" wtedy i wielokrotnie powtarzają te same czynności i rytuały, nie mogąc przejść do dalszych działań. Na płaszczyźnie językowej powtarzanie staje się niekiedy natręctwem, jakby dzieci nie mogły uwolnić się od „wezbranych, rwących potoków” mowy - według przywołanej wcześniej metafory Uty Frith. Marta Korendo zwraca uwagę na związek telewizji i gier komputerowych z uzależnieniami dzieci, również od zasłyszanych w nich tekstów. Bodźce płynące z tych mediów wpływają na dzieci, które zachowują się, jakby były zahipnotyzowane, a także charakteryzują się podwyższonym poziomem agresji i autoagresji (ibid. 2013: 90-91).

W związku z tym nasuwa się wręcz pytanie, czy „niewinna” i czasami - pod względem estetycznym - czarująca otoczenie echolalia (mam tu na myśli powta- 
rzanie tekstów wzbogaconych wyszukanymi środkami językowymi, z zachowaniem oryginalnej intonacji aktorskiej) jest zjawiskiem pozytywnym czy negatywnym. Jak zauważa Barbara Winczura, poglądy co do funkcji echolalicznych wypowiedzi dzieci autystycznych są sprzeczne. Za pozytywny wpływ echolalii uznawał choćby Leo Kanner, który uważał, że echolalia jest oznaką pozytywnego stosunku dziecka do powtarzanych treści (por. Winczura 2008: 35). Inaczej postrzegają to zagadnienie badacze o podejściu terapeutycznym. Marta Korendo mówi wręcz o konieczności podjęcia wysiłku wyłączenia echolalii, choćby na krótko, i wskazuje praktyczne zalecenia (Korendo 2013: 89-92).

\section{„Mówienie za kimś" - na czym ono polega?}

W celu lepszego opisania i zrozumienia „mowy za kimś” poddałem wnikliwej obserwacji niskofunkcjonującą dorosłą osobę z autyzmem, w której mowie występuje głównie echolalia ${ }^{12}$. Przedmiotem mojego zainteresowania będą więc wypowiedzi tego typu. Tym samym nie będę zajmował się bogatą stereotypią Marcina (dalej M.), gdyż według mnie nie wnosi ona niczego nowego do istoty „mówienia za kimś”. Różnić ją będzie jedynie szerszy zakres powtarzanego „za kimś” tekstu, a także pojawianie się tego typu echolalii bez wyraźnej przyczyny. Sama funkcja stereotypii językowej i pozajęzykowej jest tematem zbyt rozległym i powinna być przedmiotem zainteresowania w osobnej publikacji.

Wnioski, jakie nasuwają się z obserwacji M., są ciekawe, bo jego mowa echolaliczna prezentuje poziom wyższy niż opisywana w literaturze przedmiotu echolalia bezpośrednia lub odroczona, która charakteryzuje się zazwyczaj wiernym powtarzaniem słów lub dłuższych tekstów. Natomiast zasłyszane przez M. wypowiedzi ulegają pewnego rodzaju twórczej modyfikacji.

M., złapany przez matkę na gorącym uczynku podjadania produktów nieodpowiednich dla jego diety, odszedł, po czym - po dłuższej chwili - w całkiem innej części mieszkania wypowiedział następujący tekst:

(1) Nie przesadziłeś z tym jedzeniem? Nieeee!

12 Podane przykłady pochodzą z września i października 2019 r., zaobserwowane zostały u 30-letniego Marcina, który zaczął mówić w wieku czterech lat. Jego kompetencja gramatyczna jest dobra przy tworzeniu form fleksyjnych i najczęściej powtarzanych zdań. Przy próbach odpowiedzi na pytania swoimi słowami jest ona znacznie obniżona, co widać głównie na płaszczyźnie budowania zdań minimalnych i prozodii. W jego zachowaniu uwidaczniają się stereotypie. Marcin nie toleruje zmian, więc porządkuje przedmioty w swoim otoczeniu według przyzwyczajenia. Wykonuje szereg bezproduktywnych czynności. Wypowiada mnóstwo tekstów zasłyszanych z różnych źródeł, głównie z filmów. „Mówienie za kimś” w jego wykonaniu jest często bezkrytyczne, gdyż powtarza słowa tak, jak je słyszy, nieraz błędnie, np. zoo zamiast $z \nmid o, z d r a d a$ zamiast $z d r a d z a$, pilnuj zamiast filuj. 
Zapytałem M. podczas spaceru po lesie, czy nie boi się wilków, które są o wiele groźniejsze od złych psów. Odpowiedział, że nie, a później dodał:

(2) Ja ich pozabijam i pokraję.

M. bardzo mocno zamknął drzwi od samochodu. Kiedy mu zwróciłem uwagę, żeby tak nie trzaskał, i pokazałem mu, jak powinien to robić, po pewnej chwili krzyknął:

(3) Walcie, ile wlezie!

Kiedyś sąsiadka, widząc, że z M. zamierzamy wejść do klatki schodowej, przytrzymała nam drzwi. M. wszedł pierwszy przed nią. Kiedy mu mówiłem, jak należy się grzecznie zachować, skomentował to słowami:

(4) Nie dzieje się nic podejrzanego.

Innym razem, kiedy zwracałem mu uwagę na niewłaściwe zachowanie, wyrecytował w formie zasady, jakby „do siebie”:

(5) Trzeba się zachować porządnie.

Kiedy przyjechaliśmy w okolice lasu i zaczęliśmy spacerować, M. powiedział krótko, że nie chce iść dalej. Kiedy mu zakomunikowałem zdecydowanie, że się trochę przejdziemy, przypomniał sobie inne moje słowa, które wcześniej wypowiedziałem w podobnej sytuacji:

(6) Nie po to żeśmy przyjechali, żeby wracać do domu.

Na tym tle wyróżnia się „mówienie za kimś” o charakterze bardziej emocjonalnym, niekiedy agresywnym:

(7) Przykro mi, że doprowadziłem własną matkę do łez, ale sama się o to prosiła.

(8) Zostaw mnie, nie jesteś moim rodzicem.

(9) Nie martw się, nie będę cię bić, mam lepsze sposoby na zemstę.

We wszystkich przykładach (1)-(9) pojawia się pewnego rodzaju kontynuacja. Jej mechanizm działa w ten sposób, że usłyszany tekst (w postaci słowa, wyrażenia, wypowiedzenia itp.) umożliwia odbiorcy dokończenie dalszej jego części (echolalia bezpośrednia) albo utworzenie tekstu jakoś związanego $\mathrm{z}$ wywołanymi słowami 
i innymi jednostkami językowymi ${ }^{13}$. Kontynuacja opiera się na wyszukiwaniu w pamięci (tak jak wyszukiwarka internetowa wydobywa określone słowo z zasobu mnóstwa jego połączeń z innymi) elementów kojarzących się z danym słowem, najczęściej na zasadzie przyległości. Okazuje się więc, że nawet w echolalii jest wykorzystywany kontekst językowy (gramatyczny), ponieważ odbiorca, bazując na znajomości konwencjonalnych struktur językowych, łatwo powtarza zasłyszane teksty. Echolalia ma więc charakter metonimiczny (Kominek 2014b).

W produkowaniu tekstów (1)-(9) umiejętność językowa, czyli swoistego rodzaju „wyszukiwarka” sięga głębiej - do kontekstu sytuacyjnego (Jakobson 1989a: 157). Kontekst ten (konsytuacja) obejmuje warunki, w których odbywa się dany akt mówienia. Odbiorca, a jest nim w przytoczonych przykładach osoba z autyzmem, szuka konsytuacji, czyli podobnej sytuacji, zdarzeń, czasu i miejsca, a także relacji między światem a nim samym. Często chodzi o sytuacje wychowawcze, w których ktoś komuś wskazuje, jak się ma zachować, np. ojciec synowi. Wskazówki mają postać skonwencjonalizowanych formuł, a te łatwo zapamiętać. Na pomoc przychodzą osobom takim jak M. sytuacje pochodzące z filmów. Ponieważ M. zna ich setki, i to dokładnie - niektóre oglądał wiele razy - sięgnięcie do konkretnych, potrzebnych scen i tekstów przychodzi mu stosunkowo łatwo ${ }^{14}$. Zawsze jednak jest to mówienie „za kimś”, chociaż sytuacji źródłowej bardzo często inne osoby sobie nie uświadamiają, chyba że dotyczy to sytuacji powszechnie znanej (2) lub nawiązuje ona do wspólnego doświadczenia, np. zwracania autykowi uwagi na niestosowne zachowanie. Dla obserwatorów znajdujących się z boku konteksty są w większości niezrozumiałe.

W tekstach (7)-(9) warunkiem występowania reakcji bardzo emocjonalnej są konsytuacje również o charakterze emocjonalnym i działa tu mechanizm: siła reakcji równa się sile akcji. Na krzyk autyk odpowiada krzykiem, złością albo innym rodzajem emocji negatywnej, np. agresją słowną. Teksty te emanują dosyć dużym ładunkiem takich uczuć. Ponieważ zostały wyszukane w bazie, są znacznie silniejsze od tekstów, które byłyby własną twórczością słowną. Powtarzanie „za kimś”, w sytuacji korekty zachowania odbiorcy, dzieje się więc w zależności od tego, co je poprzedzało: delikatne zwrócenie uwagi czy raczej mocna reprymenda. Świadczy to o tym, że autyk przyswaja sobie konsytuacje źródłowe (porównując je z rzeczywistymi) nie tylko słowo w słowo, ale także ze wszystkimi szczegółami (dokładnym tempem mowy, intonacją itp.). Nie znając bardzo często właściwych znaczeń słów, autyk wyczuwa nastrój i napięcie, które im towarzyszą.

13 Tego typu wypowiedzi echolaliczne opisywałem m.in. w: Kominek 2014b: 6o-61.

14 Przypomina to znany szerokiej rzeszy odbiorców film Wystarczy być według powieści Jerzego Kosińskiego pod tym samym tytułem (1971). Upośledzony bohater tej opowieści, dotknięty niewątpliwie autyzmem (w jego postać wcielił się Peter Sellers), całe życie nie wychodził poza dom i ogród i zna życie tylko z telewizji. Sięga więc po wiedzę o każdej rzeczy do pamięci składającej się z obrazów telewizyjnych. 


\section{Czy język osób z autyzmem pełni funkcję komunikacyjną?}

Drugie, być może najważniejsze pytanie - obok pytania o tzw. siódmą funkcję języka - zostało zadane dużo wcześniej i dotyczy pierwszej, najważniejszej funkcji. Jak wiadomo, R. Jakobson mówi o sześciu podstawowych funkcjach komunikacji językowej: poznawczej, poetyckiej, fatycznej, emotywnej, konatywnej, metajęzykowej (ibid.: 88). Każda $\mathrm{z}$ nich jest podstawowa w tym sensie, że razem z pozostałymi tworzy całość w przekazie komunikatu językowego. Twierdzenie Jakobsona koresponduje z innymi poglądami, że język służy wielu celom i że trudno wskazać jeden podstawowy. „Odmienność każdorazowego aktu mowy polega nie na monopolu którejś z tych funkcji, ale na odmiennym porządku hierarchicznym" (ibid.: 82). Zdaniem Jean Aitchison język pełni tak wiele złożonych funkcji, że poszukując tej pierwotnej, a tym samym podstawowej roli języka, trzeba uwzględnić to, co mu wychodzi najlepiej, a z czym radzi sobie źle. W centrum Aitchison stawia funkcję informacyjną (poznawczą), zaznaczając jednak sfery, które językowi sprawiają problemy: mówienie o przestrzeni i o uczuciach. Oprócz funkcji informacyjnej centralne miejsca zajmują funkcje społeczne: podtrzymywanie więzi społecznych (funkcja fatyczna) i wywieranie wpływu na innych (funkcja konatywna, zwana przez językoznawców perswazyjną) (Aitchison 2002: 30-42). Daniel L. Everett uważa za centralne dwie funkcje: fatyczną, którą traktuje jako językowy ekwiwalent pielęgnowania i troski o innych, oraz kulturową (język bez wiedzy nie może funkcjonować) (Everett 2019: 234-235, 369-370). Na pierwszorzędne znaczenie funkcji fatycznej zwracał też uwagę Bronisław Malinowski, mówiąc o społecznej doniosłości „mówienia dla samego mówienia” (Malinowski 1987). Podobnie uważa Robin Dunbar, antropolog i psycholog ewolucyjny, którego zdaniem funkcja fatyczna w języku rozwinęła się - w celu cementowania grup towarzysko-społecznych - poprzez wymianę informacji, głównie towarzyskich (Dunbar 2017: 170, 194).

Schemat komunikacji językowej należy rozumieć jako współwystępowanie wszystkich funkcji w akcie komunikacji niezależnie od funkcji dominującej - jak pisał R. Jakobson - nawet jeśli w jednej ze sfer komunikacji użytkownik języka porusza się lepiej lub gorzej czy wydaje się, że któraś z funkcji jest w komunikacie językowym nadrzędna. Sam R. Jakobson rozważa w kluczowym dla swej teorii artykule rolę funkcji poznawczej na tle funkcji poetyckiej, pisząc, że jest ona zasadniczym celem licznych komunikatów obok „ubocznego uczestnictwa również innych funkcji w tych komunikatach" (Jakobson 1989a: 82). Funkcja poznawcza współwystępuje jako nadrzędna np. w wypowiedziach, w których chodzi o wyrażenie postawy mówiącego wobec tego, o czym on mówi (funkcja emotywna). Wyrażając gniew lub ironię, wnosi tym samym z góry zamierzoną informację. Podobny układ występuje w komunikatach wyrażających pewnego rodzaju nacisk na odbiorcę ze strony nadawcy: „chciałbym/oczekuję, abyś to (dla mnie) zrobił”15. Tę wartość poznawczą

$15 \mathrm{Nb}$. do tych trzech funkcji: poznawczej, emotywnej i konatywnej odnosił się tradycyjny model językowy Karla Bühlera (1934), w którym jako element umieszczany na górze symbolicznego trójkąta znajdowała się opisywana rzeczywistość, czyli treść poznawcza. 
można wskazać w pozostałych elementach schematu komunikacji, ponieważ zarówno sposób prezentacji rzeczywistości (funkcja poetycka), jak i podtrzymywanie relacji między uczestnikami komunikacji (funkcja fatyczna) oraz zwrócenie uwagi na język sposobu przekazu (funkcja metajęzykowa), w formie zamierzonej bądź niezamierzonej, opierają się na mówieniu o jakiejś rzeczywistości: pozajęzykowej, wewnątrzjęzykowej i sytuacyjnej. Jak pisze R. Dunbar, ,język wyewoluował, by umożliwić ludziom wymianę informacji" (2014: 142). Odpowiadając zatem na pytanie o podstawową funkcję języka, należy stwierdzić, że wszystkie wymienione funkcje charakteryzują język jako byt społeczny, więc podstawową funkcją jest funkcja komunikacyjna języka ${ }^{16}$.

Jeśli funkcja ta jest konstytutywna i prymarna dla każdego wytworu (komunikatu) językowego, to rodzi się pytanie, czy określa również najpełniej język osób ze spektrum autyzmu. Ponieważ na nazwanie różnych stadiów zaburzeń autystycznych stosuje się powszechnie wyrażenie kontinuum cech autystycznych ${ }^{17}$, również mowę (i język) należy traktować w ten sposób. Przyjąłem jednak wcześniej założenie, że istotą języka autyków jest mowa nieautonomiczna, kopiowana i nieintencjonalna, wyrażająca się dokładnie w ten sposób w echolalii, więc w dalszym ciągu moje uwagi będą dotyczyły tego sposobu komunikacji.

Język osób powtarzających „za kimś” (zob. przykłady (1)-(9)) mógłby wydawać się językiem w pełni komunikatywnym. Mówię „mógłby”, gdyż jak się okazuje przy bliższej analizie, tak nie jest. Wymiana informacji między nadawcą a odbiorcą wymaga tzw. teorii umysłu, a taką osoby $\mathrm{z}$ autyzmem mają niewielką albo w ogóle jej nie posiadają. Podobnie nie pojawia się u nich funkcja fatyczna i metajęzykowa. Niektóre funkcje, jak emotywna i konatywna, mogłyby występować w mowie autyków, jeśli brano by pod uwagę niezamierzoną ekspresję nadawcy i wpływanie na odbiorcę, a tego R. Jakobson nie uwzględnił w swojej teorii (Grzegorczykowa 2008: 49). Podobnie można by się doszukiwać funkcji poetyckiej, ponieważ wiele ripost echolalicznych emanuje czysto estetycznym skupieniem się na przekazie językowym, jakby dla samego języka, gdyż w stereotypiach pochodzących z różnych mediów teksty pełniące funkcję poetycką są przemyślane i bardzo często pojawia się w nich nietuzinkowa gra słów. Gdyby brać pod uwagę tzw. siódmą funkcję języka, to również można by w niezamierzonych, „tajemniczych” tekstach autyków doszukiwać się magicznej, prorockiej, niezwykle perswazyjnej mocy słów, o czym świadczą przypadki różnych osób znajdujących się w izolacji społecznej, np. rosyjskich jurodiwych. Otaczano ich, jak wynika $\mathrm{z}$ wielu relacji historycznych, niemalże reli-

16 Zob. m.in.: Aitchison 2002; Tomasello 2016; Dunbar 2017; Everett 2019.

17 Chodzi o termin funkcjonujący od połowy lat 8o. XX w., który oznacza traktowanie autyzmu w sposób skalarny: od postaci głębokich zaburzeń do łagodnego „muśnięcia” autyzmem. Według Lorny Wing, brytyjskiej psychiatry, „cechy autystyczne o różnym stopniu natężenia występują $\mathrm{w}[\ldots]$ różnorodnych zestawieniach u osób o rozbieżnych zdolnościach intelektualnych i społecznych" (cyt. za: Donvan, Zucker 2017: 307). 
gijną czcią, ponieważ wygłaszali, zapewne z powodu zaburzeń psychicznych, różne dziwne teksty, którym nadawano ponadnaturalne znaczenie. Tego typu praktyka społeczna stała się też motywem wspomnianej książki Jerzego Kosińskiego. Wygłaszane przez głównego bohatera proste, banalne i naiwne sądy są przez grupę przeintelektualizowanych, wpływowych osób podnoszone do rangi odkrywczych praw politycznych i ekonomicznych.

Jeżeli odbierzemy tym funkcjom wartość komunikacyjną, to czym będzie to, co nazywamy jednak językiem? Nie będzie on mógł w pełni intencjonalnie, w sposób zamierzony pełnić żadnej z funkcji podrzędnych: emotywnej, konatywnej, poetyckiej, a także fatycznej i metajęzykowej. Tym bardziej język taki nie będzie mógł się wznieść do poziomu sprawczego i perswazyjnego. Język osób mówiących „za kimś” pozostanie wówczas bezmyślnym naśladowaniem, „papugowaniem”, chociaż nieraz sprawia wrażenie bardzo inteligentnego i efektownego sposobu uczestniczenia w komunikacji językowej. Elementy tego języka, chociaż są nimi nawet poprawne gramatycznie zdania, to cząstki bez znaczenia, które można porównać np. do głosek. Same dźwięki mowy nie mają bowiem autonomicznego znaczenia. Podobnie taki język, jakim posługują się osoby echolaliczne, jest quasi-językiem, pustym językiem, językiem dla samego języka ${ }^{18}$.

\section{Jaka funkcja jest najbardziej charakterystyczna dla języka autyków?}

Pozostaje odpowiedź na pytanie, czym zatem jest ten rodzaj mowy autyków, jeśli mówienie „za kimś” jest językiem bez komunikacji. Co jest istotą mowy echolalicznej, nieintencjonalnej i niekomunikacyjnej? Zgodnie z założeniami kognitywistycznymi język manifestuje wspólistnienie i wspólną grę z innymi rodzajami aktywności człowieka. Takie poglądy - w odniesieniu do języka osób z autyzmem - głosił już w latach 40. ubiegłego wieku Leo Kanner, jeden z prekursorów badań nad autyzmem. Zauważył on, że wśród autyków nie ma fundamentalnej różnicy między osobami znajdującymi się na różnych etapach rozwoju, co pokazała Lorna Wing za pomocą wizualizacji objawów autyzmu jako kontinuum tych cech: od najcięższych do najłagodniejszych. Osoby $\mathrm{z}$ autyzmem, niezależnie od miejsca zajmowanego na „linii” rozwoju, wykazują tego samego typu stereotypie zachowań, np. powtarzają uporczywie te same pytania i teksty, wirują wokół osi swojego ciała czy przestrzegają rutynowych, sztampowych rytuałów. Otóż wszystkie te zachowania są według

18 Przyjęcie takiego założenia jest uproszczeniem, ponieważ wypowiedzi „za kimś” nie do końca są niekomunikatywne. Podobnie jak osoby neurotypowe przyswajają sobie język z określonymi funkcjami, np. emotywną czy konatywną, również u autyków część wypowiedzi (nawet niezamierzonych) nosi znamiona tych funkcji. Mimo braku badań ilościowych można by podać przykłady tego typu komunikatów. 
L. Kannera „solipsystycznymi formami zachowań autostymulacyjnych” (cyt. za: Silberman 2017: 181). Za L. Kannerem również inni badacze mówią o echolaliach i stereotypiach językowych jako o nieuświadomionej autostymulacji. Nasuwa to przypuszczenie, że podstawową funkcją języka jest dla autyków funkcja autostymulacyjna. Język w tym przypadku służy tylko tym osobom, jest zamkniętym środkiem skupienia uwagi na sobie. Czasami, tak jak inne zachowania autostymulacyjne, pobudza autyków do bezproduktywnej aktywności, a niekiedy stanowi bufor bezpieczeństwa wobec silnego napięcia emocjonalnego i lęku. Zdaniem terapeutów należy dążyć za wszelką cenę do wyłączenia tego typu zachowań, ale stuprocentowo skuteczne działania są wręcz niemożliwe lub wymagają systematycznego oddziaływania. Sam bowiem mechanizm tak szybko nie zniknie, ponieważ tworzy się klasyczny stan uzależnienia (Korendo 2013: 88-92). Autostymulacja jest silnym konkurentem dla komunikacji, więc tylko od właściwej terapii zależy ukomunikacyjnienie autyka i jego uspołecznienie. Być może w przyszłości, która jawi się nam jako era neuronauki, będziemy w stanie określić, jakie jest zadanie danego typu „symulacji”, czyli rozumienia komunikatów językowych przy przetwarzaniu danego aspektu użycia języka, i będziemy mogli lepiej zrozumieć, jak ta symulacja lub jej brak wpływają na zaburzenia językowe ${ }^{19}$. Na przykład dotarcie do uszkodzeń neuronów w mózgu odpowiedzialnych za doznania motoryczne i doświadczanie obiektów lub za każdą inną sprawność najprawdopodobniej przywróciłoby umiejętność korzystania z symulacji tego typu doznań (por. Bergen 2018: 319-320).

\section{Literatura}

Aitchison J., 2002, Ziarna mowy. Początki i rozwój języka, przeł. M. Sykurska-Derwojed, Warszawa.

Austin J.L., 1974, Performatywy i konstatacje, [w:] M. Hempoliński (red.), Brytyjska filozofia analityczna, Warszawa, s. 235-244.

Austin J.L., 1993, Jak działać stowami. Rozprawy i wykłady filozoficzne, [w:] idem (red.), Mówienie i poznawanie. Rozprawy i wykłady filozoficzne, przeł. B. Chwedeńczuk, Warszawa, s. 311-335.

BARTMiński J., Grzegorczykowa R. (red.), 1991, Język a kultura, t. 4: Funkcje języka i wypowiedzi, Wrocław.

Bergen B.K., 2018, Latające świnie. Jak umysł tworzy znaczenie, przeł. Z. Lamża, Kraków. Binet L., 2018, Siódma funkcja języka, przeł. W. Dłuski, Kraków.

Вовкошicz-Lewartowska L., 2014, Autyzm dziecięcy. Zagadnienia diagnozy $i$ terapii, wyd. 7, Kraków.

19 Chodzi tu o nową propozycję badawczą, nazwaną przez Benjamina Bergena hipotezą ucieleśnionej symulacji, w myśl której „,rozumiemy język, symulując w naszym umyśle, jak by to było doświadczać tego, co on opisuje” (Bergen 2018: 27). 
Budziszewska W., 1991, Z problematyki obcości w języku magii, [w:] J. Bartmiński, R. Grzegorczykowa (red.), Język a kultura, t. 4: Funkcje języka i wypowiedzi, Wrocław, s. 87-92.

Burszta W., 1991, Mowa magiczna jako przejaw synkretyzmu kultury, [w:] J. Bartmiński,

R. Grzegorczykowa (red.), Język a kultura, t. 4: Funkcje jezyka i wypowiedzi, Wrocław, S. $93-104$.

BüHler K., 1934, Sprachtheorie. Die Darstellungsfunktion der Sprache, Jena.

Donvan J., Zucker C., 2017, Według innego klucza. Opowieść o autyzmie, przeł. A. Homańczyk, Kraków.

Dunbar R., 2014, Nowa historia ewolucji człowieka, przeł. B. Kucharzyk, Kraków.

Dunbar R., 2017, Pchły, plotki a ewolucja języka. Dlaczego człowiek zaczął mówić?, przeł. T. Pańkowski, Kraków.

Engelking A., 1991, Rytuały słowne w kulturze ludowej. Próba klasyfikacji, [w:] J. Bartmiński, R. Grzegorczykowa (red.), Język a kultura, t. 4: Funkcje języka i wypowiedzi, Wrocław, s. 75-85.

Everett D.L., 2019, Jak powstał język. Historia największego wynalazku ludzkości, przeł. A. Tuz, Warszawa.

Frith U., 2008, Autyzm. Wyjaśnienie tajemnicy, przeł. M. Hernik, G. Krajewski, Gdańsk.

GRÜN A., 2016, Waga słów - siła milczenia, czyli nowa kultura rozmowy, przeł. B. Grunwald-Hajdasz, Poznań.

Grzegorczy Kowa R., 1991, Problem funkcji języka i tekstu w świetle teorii aktów mowy, [w:] J. Bartmiński, R. Grzegorczykowa (red.), Język a kultura, t. 4: Funkcje języka i wypowie$d z i$, Wrocław, s. 11-28.

GrZegorCzy Kowa R., 2008, Wstęp do językoznawstwa, Warszawa.

JАковson R., 1989a, W poszukiwaniu istoty języka. Wybór pism, wybór, red. i wstęp M.R. Mayenowa, t. 1-2, Warszawa.

JАковSOn R., 1989b, Poetyka w świetle językoznawstwa, [w:] idem, W poszukiwaniu istoty języka. Wybór pism, wybór, red. i wstęp M.R. Mayenowa, t. 2, Warszawa, s. 77-124.

Kominek A., 2014a, Mówi się trudno... O rodzajach kompetencji językowej (i komunikacyjnej) osób $z$ autyzmem, „Studia Filologiczne UJK”, t. 27, s. 161-171.

KomineK A., 2014b, Zakłócenia $w$ dziedzinie podobieństwa $w$ komunikacji językowej osób $z$ autyzmem - i co z tego wynika, „LingVaria” nr 2 (18), s. 55-68, https://doi.org.10.12797/ LV.09.2014.18.05.

Konstantareas M.M., 1992, Autyzm jako deficyt języka i komunikowania się, [w:] M.M. Konstantareas, E.B. Blackstock, Ch.D. Webster, Autyzm, przeł. K. Hipp, Warszawa, s. 68-81.

Korendo M., 2013, Językowa interpretacja świata w wypowiedziach osób z zespołem Aspergera, Kraków.

Malinowski B., 1987, Ogrody koralowe i ich magia. Studium metod uprawy ziemi oraz obrzędów towarzyszacych rolnictwu na Wyspach Trobrianda. Język magii i ogrodnictwa, Warszawa.

MARKIEWICZ K., 2004, Możliwości komunikacyjne dzieci autystycznych, Lublin.

Minczakiewicz E., 1994, Z badań nad rozwojem mowy dzieci autystycznych, [w:] W. Dykcik (red.), Autyzm, kontrowersje i wyzwania, Poznań, s. 91-106.

Pisula E., 2012, Autyzm. Od badań mózgu do praktyki psychologicznej, Sopot.

SAdowska E., 2011, Zaburzenia komunikacji w autyzmie - podstawowe trudności diagnozy i terapii logopedycznej, „Poradnik Językowy” nr 9, s. 36-51. 
SeARle J., 1980, Czym jest akt mowy?, przeł. H. Buczyńska-Garewicz, „Pamiętnik Literacki” LXXI, s. 241-248.

SEARle J., 1987, Czynności mowy. Rozważania z filozofii języka, przeł. B. Chwedeńczuk, Warszawa.

Silberman S., 2017, Neuroplemiona. Dziedzictwo autyzmu i przyszłość neuroróżnorodności, przeł. B. Kotarski, Białystok.

Tomasello M., 2016, Dlaczego współpracujemy. Na podstawie serii wykładów Tannera o wartościach ludzkich, wygłoszonych przez autora w Stanfordzie w 2008 r., przeł. Ł. Kwiatek, Kraków.

Winczura B., 2008, Dziecko z autyzmem. Terapia deficytów poznawczych a teoria umysłu, Kraków.

\section{"Talking after somebody". A Language Without Communication Summary}

The paper examines "talking after somebody", i.e. the phenomenon of echolalia which is especially characteristic for low-functioning people with autism. The paper shows that such speech is unintentional and uncommunicative. The language of autistic persons also does not fulfill the causative or persuasive role. It does, however, perform the function of uncoscious self-stimulation for those people. According to therapists, this type of behaviour should be eliminated at all cost. 